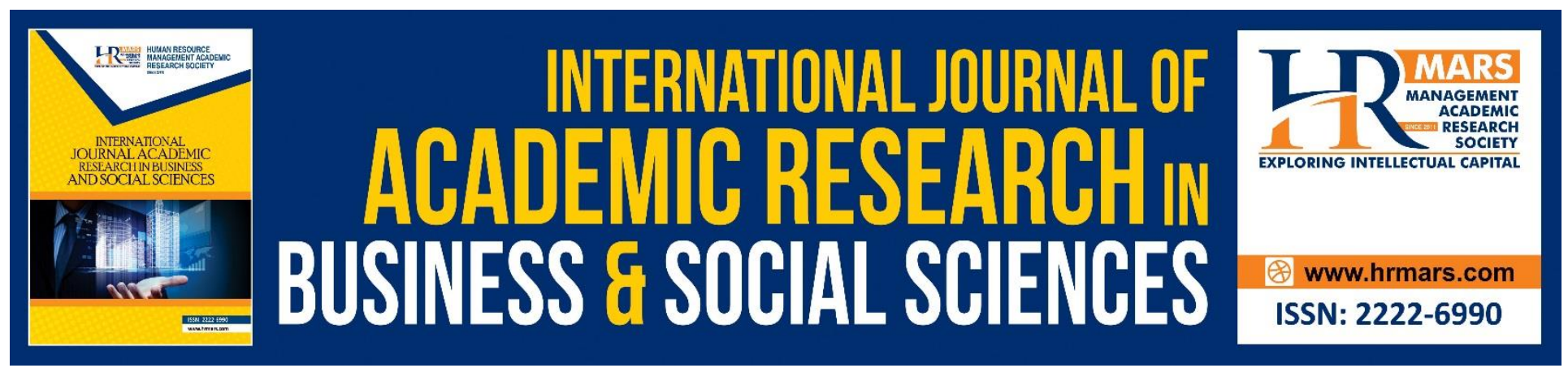

\title{
Applying Ajzen's Theory of Planned Behaviour on the Participation of Micro-Entrepreneurs in Micro-Takaful
}

\begin{abstract}
Azila Abdul Razak, Fidlizan Muhammad, Mohd Yahya Mohd Hussin, Mohamad Rohieszan Ramdan \& Fatimah Salwa Abd. Hadi
\end{abstract}

To Link this Article: http://dx.doi.org/10.6007/IJARBSS/v8-i11/5340

DOI: $10.6007 /$ IJARBSS/v8-i11/5340

Received: 28 Oct 2018, Revised: 17 Nov 2018, Accepted: 03 Dec 2018

Published Online: 04 Dec 2018

In-Text Citation: (Razak, Muhammad, Hussin, Ramdan, \& Hadi, 2018)

To Cite this Article: Razak, A. A., Muhammad, F., Hussin, M. Y. M., Ramdan, M. R., \& Hadi, F. S. A. (2018). Applying Ajzen's Theory of Planned Behaviour on the Participation of Micro-Entrepreneurs in Micro-Takaful. International Journal of Academic Research in Business and Social Sciences, 8(11), 1666-1679.

Copyright: (C) 2018 The Author(s)

Published by Human Resource Management Academic Research Society (www.hrmars.com)

This article is published under the Creative Commons Attribution (CC BY 4.0) license. Anyone may reproduce, distribute, translate and create derivative works of this article (for both commercial and non-commercial purposes), subject to full attribution to the original publication and authors. The full terms of this license may be seen at: http://creativecommons.org/licences/by/4.0/legalcode

Vol. 8, No. 11, 2018, Pg. 1666 - 1679

http://hrmars.com/index.php/pages/detail/IJARBSS

JOURNAL HOMEPAGE

Full Terms \& Conditions of access and use can be found at http://hrmars.com/index.php/pages/detail/publication-ethics 


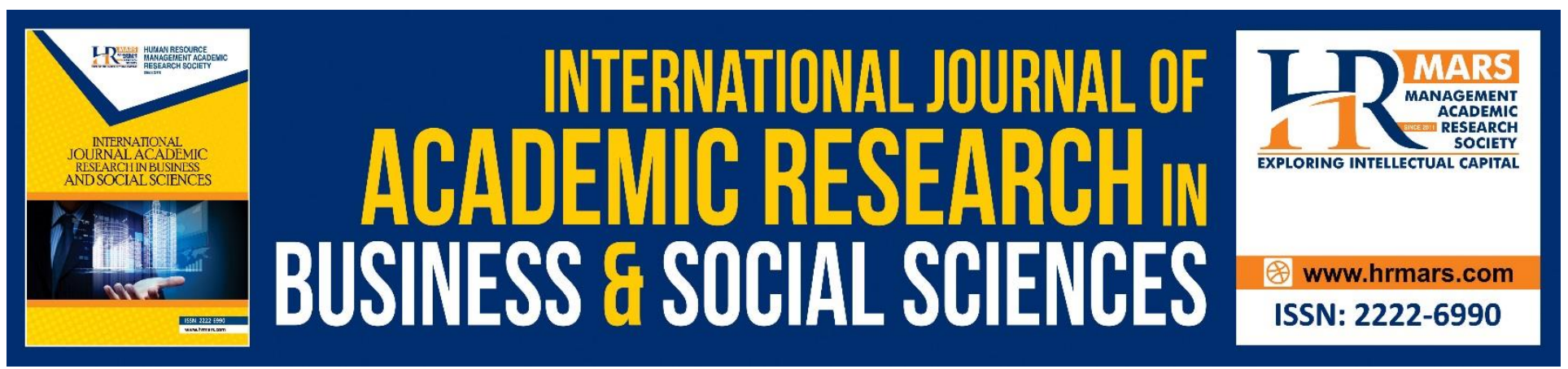

\title{
Applying Ajzen's Theory of Planned Behaviour on the Participation of Micro-Entrepreneurs in Micro-Takaful
}

\author{
Azila Abdul Razak, Fidlizan Muhammad, Mohd Yahya Mohd Hussin, \\ Mohamad Rohieszan Ramdan \& Fatimah Salwa Abd. Hadi \\ Department of Economics, Faculty of Management and Economics, Universiti Pendidikan Sultan \\ Idris, Malaysia
}

\begin{abstract}
This study attempts to apply the theory of planned behaviour (TPB) in predicting the behaviour of micro-entrepreneurs towards their participation in micro-takaful. The influence of TPB model such as attitude, subjective norms and perceived behavioural control factors and tendency of microtakaful participation are analyzed using the multiple linear regression analysis. This study uses a questionnaire instrument involving of 135 micro-entrepreneurs in Perak. The findings reveal that attitude, subjective norms and perceived behavioural control factors have significant influenced on the tendency of micro-takaful participation. The implication of the study shows that takaful operators and policy makers need to take into account the factors that exist in the theory of planned behaviour when planning a strategy and making decisions related to the micro-takaful scheme.
\end{abstract}

Keywords: Micro-Takaful, Theory of Planned Behaviour, Micro-Entrepreneurs

\section{Introduction}

Takaful is an Islamic finance instrument which provides financial protection against unexpected risks such as disaster, death or business loss. The word 'takaful' is borrowed from the Arabic word 'kafala' which means guarantee or responsibility (Billah, 2003). As an alternative to conventional insurance, takaful was introduced to apply the element of tabarru' (donation) and profit-sharing which does not involve the elements of gharar (uncertainty) and maisir (gambling) in the insurance contract (Mohamed Sherif \& Nor Azlina, 2013). Based on Table 1, the growth of takaful fund assets had grown from RM20,934 million in 2013 to RM26,792 million in 2016. As for the size of the takaful market compared to the overall insurance market, this showed a good increase from 8.96 percent in 2013 to 9.68 percent in 2016 .

In line with the government's aim related to financial inclusion, in 2010, Central Bank of Malaysia had urged the takaful providers to design and provide a micro-takaful scheme for lowincome groups and micro-entrepreneurs at an affordable premium (Norashikin et al., 2013) or less than RM20 (Bank Negara Malaysia, 2010). This call was in line with the increasing growth of micro- 
takaful schemes globally. The first micro-takaful scheme was introduced in Lebanon in 1997 and it has been steadily growing since January 2010 in countries such as Indonesia, Malaysia, Bangladesh, Kuwait, Sudan, United Arab Emirates, Sri Lanka, Bahrain and Pakistan. In Malaysia, there are a few micro-takaful products such as i-BRIM (Takaful Berkumpulan Rakyat 1Malaysia), fishermen's takaful, takaful for Indonesian maids, cooperative tabarru' schemes, paddy takaful protection, 1Malaysia micro-takaful protection plan (1MMPP) and others (Fatin Nabilah, 2015). Overall there are five takaful providers for the family and the public such as Etiqa Takaful, Takaful Ikhlas, AIA Takaful, Syarikat Takaful Malaysia Berhad and HSBC Amanah.

Table 1: Growth of Takaful Fund Assets (2013 to 2016)

\begin{tabular}{|c|c|c|c|c|}
\hline & 2013 & 2014 & 2015 & 2016 \\
\hline $\begin{array}{l}\text { Total } \\
\text { million) }\end{array}$ & $20,934.0$ & $22,746.0$ & $24,711.0$ & $26,792.0$ \\
\hline $\begin{array}{l}\text { Percent (\%) from } \\
\text { overall market }\end{array}$ & 8.96 & 9.25 & 9.37 & 9.68 \\
\hline
\end{tabular}

Source: Bank Negara Malaysia (2016).

However, the micro-entrepreneurs are still unaware about the use of micro-takaful for business. Micro-takaful involves business risks such as a firm's unsystematic way of managing business operations due to the lack of current technology utilization, distribution problems, lack of production capacity and customer debt collection problems (Norashikin et al., 2013) as well as mishaps such as robbery or fire at the premises (Marhanum \& Fatimah Zaharah, 2018). Empirical findings from Norashikin et al. (2013) found that micro-entrepreneurs in Johore were less aware of the differences between insurance or takaful related to business and family as well as general insurance.The respondents' participation was limited to vehicle takaful/insurance, life and housing insurance. As such, it is imperative to highlight micro-takaful products to attract participation from the micro-entrepreneurs. As shown in the study by Marhanum and Fatimah Zaharah (2018) in Kelantan, the micro-entrepreneurs' level of understanding which was related to their education level, had a significant influence on their level of awareness towards the existence of micro-takaful products.

The purpose of this study is to gain some understanding about the behavioural tendencies of micro-entrepreneurs in Perak to participate the micro-takaful schemes by looking at the role of variables in the theory of planned behaviour. The study discussion is divided into 6 parts: the first part is the introduction, the second and third parts cover the literature review and framework of study, the fourth part is the methodology, and the fifth and sixth parts cover the findings, implications and conclusion.

\section{Literature Review}

This section is related to discussion about previous studies based on the tendency to participate in micro-takaful. There are two parts of discussion: one focuses on previous studies on the theory of planned behaviour and the other focuses on previous studies on the micro-takaful scheme. 


\section{The Theory of Planned Behaviour and Previous Studies}

The construction of the theoretical framework is based on the Theory of Planned Behaviour (TPB) which was developed by Ajzen (1991). The theory is an extension of the Theory of Reasoned Action (TRA) by Fishbein and Ajzen (1975) and Ajzen and Fishbein (1980). TPB explains that the intention and tendency of an individual is influenced 3 factors which are attitude, subjective norms and perceived behavioural control. The perceived behavioural control factor has been added in TPB to refer to an individual's perception whether it is easy or difficult for him to act on something. Diagram 1 shows the model of Theory of Planned behaviour as developed by Ajzen (1991).

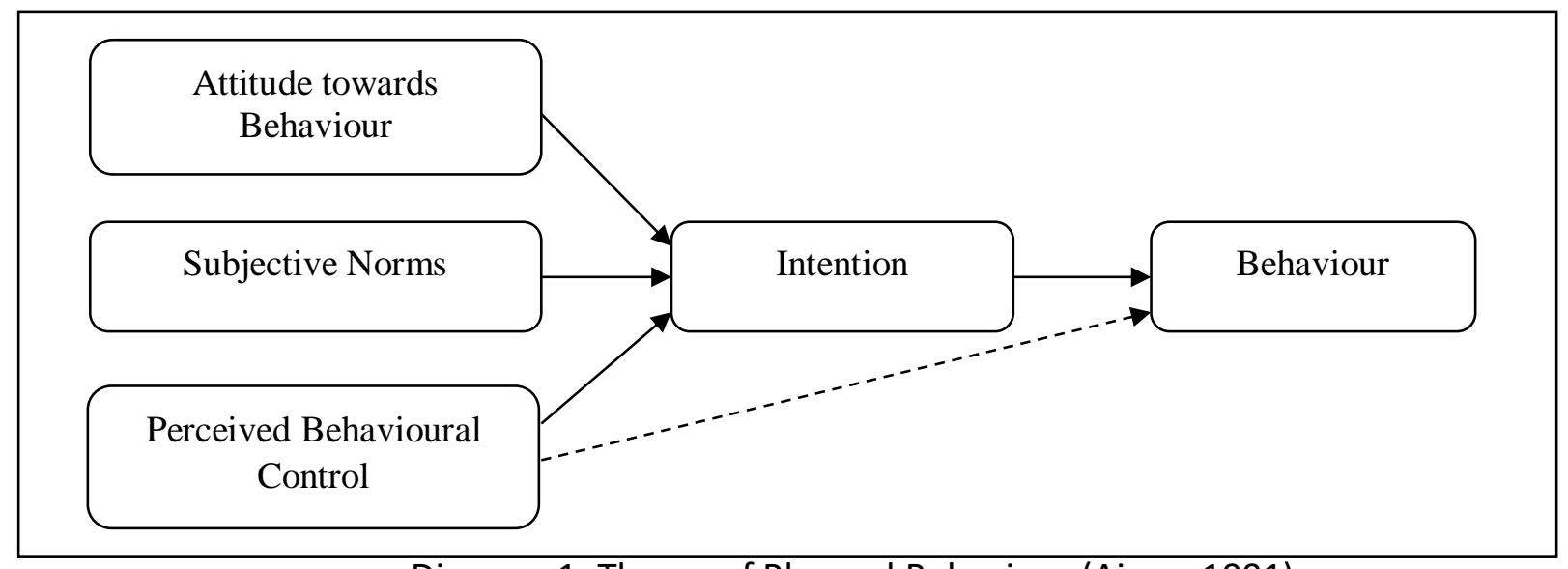

Diagram 1: Theory of Planned Behaviour (Ajzen, 1991)

The study by Maizaitulaidawati and Asmak (2016) also utilised the TPB model to look at the society's involvement in the family takaful scheme (Maizaitulaidawati \& Asmak, 2016). However, the study only focused on the tendency of societies towards the family takaful scheme. This is also evident in the study by Hanudin (2012) which applied the TPB model with the customers' willingness to use shariah-based insurance products. As such, this present study is relevant to fill in the gaps in studies related to micro-takaful.

\section{Previous Studies on the Tendency of Micro-Takaful Participation}

Previous studies connected to micro-takaful have focused on issues unrelated to the behaviour or tendency to participate in such a scheme. Instead, the issues focused on were the implementation of micro-takaful scheme in Malaysia (Fatin Nabilah, 2015), prospects of the implementation of microtakaful scheme in Malaysia (Fatin Nabilah \& Kamaruzaman, 2014), experience of the implementation of micro-takaful in selected countries (Ahmed, 2016), the effectiveness of micro-takaful (Kwon, 2010), the positive role of micro-takaful (Erlbeck et al., 2011; Kwon, 2008), the development of a micro-takaful model for the benefit of the poor and the low-income population in selected Malaysian states (Noor Ashikin, 2014), and the awareness towards micro-takaful (Marhanum \& Fatimah Zaharah, 2018; Norashikin et al., 2013). However, empirical studies on the involvement of takaful are still limited. One behavioural study had looked at the tendency of the societies to join the family takaful scheme. (Maizaitulaidawati \& Asmak, 2016). 
INTERNATIONAL JOURNAL OF ACADEMIC RESEARCH IN BUSINESS AND SOCIAL SCIENCES

Vol. 8, No. 11, Nov, 2018, E-ISSN: 2222-6990 @ 2018 HRMARS

\section{Developing the Hypothesis and Theoretical Framework}

This section discusses the relationship between the variables in this study which are attitude, subjective norms and perceived behavioural control factors towards the tendency for microentrepreneurs to join micro-takaful schemes.

\section{Attitude towards the Tendency of Micro-Takaful Participation}

Attitude is a form of mental preparation to provide either positive or negative response through the experience of an object or idea (Doane et al., 2016; Untaru et al., 2016). According to Fishbein and Ajzen (2011), a positive attitude is likely to influence someone to act on something; likewise, a negative attitude will decrease the likelihood of that person to do something.

Studies on the theory of planned behaviour have proved that attitude is the main predictor of intention and behaviour (Ajzen \& Fishbein, 1980). For example, Maizaitulaidawati and Asmak (2016) found that attitude had a positive and significant influence on the individual's intention to join a family takaful scheme. A study by Mohd Azizi et al. (2017) found a significant relationship between attitude and customers' intention to choose a shariah-based house financing product. Mohamad Rohieszan et al. (2018) also showed that attitude towards nutrition labels was able to influence the consumers' tendency to choose healthy foods. As such, this study expects that attitude can also influence the micro-entrepreneurs' tendency to participate in micro-takaful. Therefore, the hypothesis below is proposed:

$H_{1}$ : $\quad$ Attitude has a significant influence on the tendency of micro-entrepreneurs to participate in micro-takaful.

\section{Subjective Norms towards the Tendency of Micro-Takaful Participation}

Subjective norms refer to the influence or social pressure from other individuals towards an individual's attitude (Ajzen, 1991). The influence mentioned here may come from other people who are connected or related to a particular individual such as a family member, colleague or employer (Maizaitulaidawati \& Asmak, 2016). Subjective norm is a construct which is connected to behavioural intention and also actual behaviour (Ajzen \& Fishbein, 1980; Han \& Kim, 2010). Previous studies have looked into the influence of subjective norms towards the behavioural intention (Abdullah et al., 2014; Mohd Azizi et al., 2017; Hanudin, 2012). The study conducted by Hanudin (2012) on 206 respondents found that subjective norms were the main factors which influenced undergraduates in Labuan to use takaful products. On the other hand, Maizaitulaidawati and Asmak (2016) found that subjective norms did not influence an individual's intention to join the family takaful scheme as the respondents in the Klang Valley already had a high level of knowledge about the scheme; as such, the intention to join the scheme or otherwise was not influenced by any parties. Therefore, this study attempts to determine whether there is any influence between subjective norm factors and the tendency of micro-entrepreneurs to participate in micro-takaful. Based on the discussion, the following hypothesis is tested:

$\mathrm{H}_{2}$ : $\quad$ Subjective norms have a significant influence on the tendency of micro-entrepreneurs to participate in micro-takaful. 
INTERNATIONAL JOURNAL OF ACADEMIC RESEARCH IN BUSINESS AND SOCIAL SCIENCES

Vol. 8, No. 11, Nov, 2018, E-ISSN: 2222-6990 @ 2018 HRMARS

\section{Perceived Behavioural Control towards the Tendency of Micro-Takaful Participation}

Perceived behavioural control refers to an individual's perception towards the ease or difficulty to carry out certain behaviour (Ajzen, 1991). This factor has a direct effect towards behaviour as well as an indirect effect towards intention with the assumption that this element has a motivational implication on behavioural intention (Ajzen, 2002). In other words, a community which believes that they have a lot of opportunities and resource (example, time, money, cooperation from everyone) will be likely to have a high perceived control, which leads them to increase their behavioural intention (Maizaitulaidawati \& Asmak, 2016). There are a few studies which support the influence of perceived behavioural control towards intention and behaviour (Syed Shah Alam et al., 2012; Alam \& Sayuti, 2011; Nik Safiah and Norazlina, 2015). Nik Safiah and Norazlina (2015) in their study involving 308 UUM staff found that the perceived behavioural control factor was the main predictor towards the usage of Islamic personal loans, compared to other factors such as being religious, attitudes and adherence towards the religion. On the other hand, the perceived behavioural control factor did not influence the tendency to participate in agricultural takaful. Based on this discussion, the hypothesis below is tested:

$\mathrm{H}_{3}$ : Perceived behavioural control has a significant influence on the tendency of microentrepreneurs to participate in micro-takaful.

\section{Conceptual Framework of the Study}

According to Muhammad Akbar and Syed Kamaruzaman, (2011), the conceptual framework is developed to create a systematic observation towards the problem of the study by referring to previous studies. The conceptual framework developed includes the variables used to study the factors which influence the tendency of micro-entrepreneurs in Perak to join the micro-takaful scheme. This conceptual framework is shown in Diagram 2.

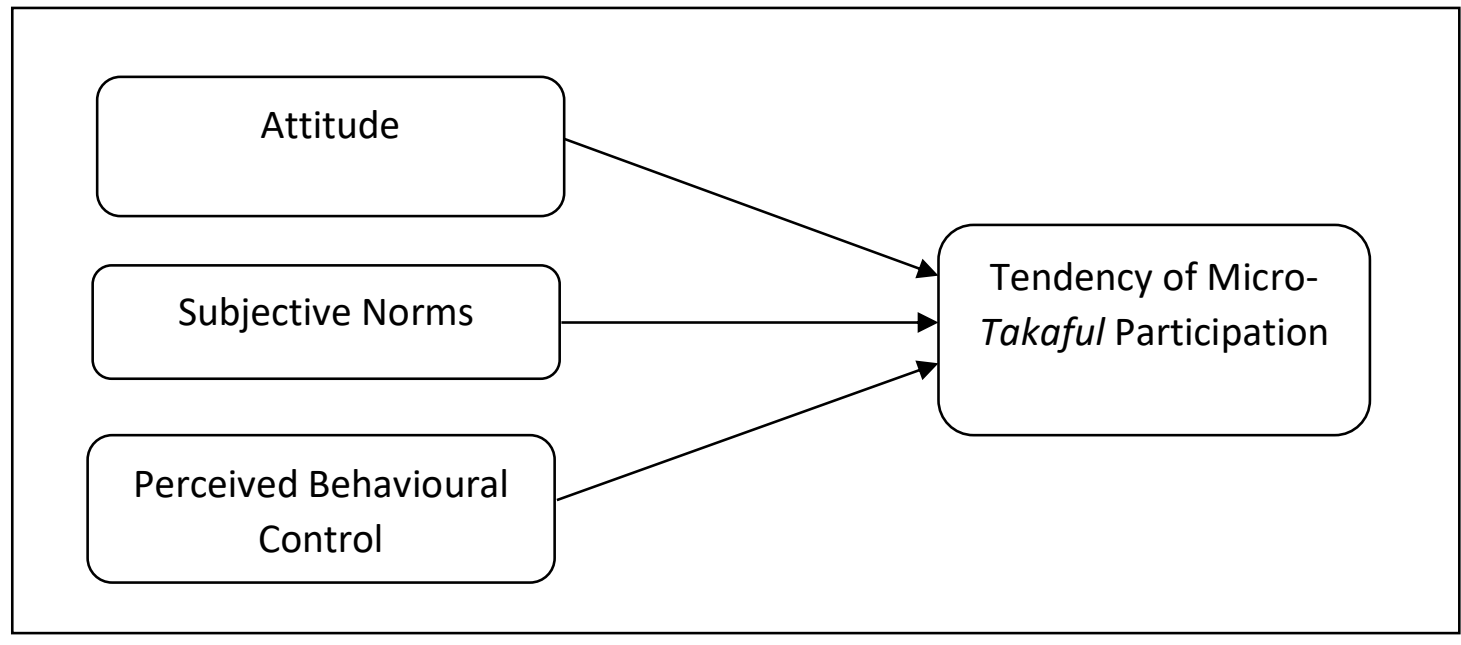

Diagram 2: Conceptual Model of Micro-Takaful Participative Behaviour 


\section{Methodology}

This study involved the agreement of micro-entrepreneurs in Perak regarding their participation in micro-takaful. The Perak state was chosen as the study location due to the development of the small and medium industries (SMEs) with a total of 75,140 industries which represented 8.3 percent of the whole total of SMEs in Malaysia (Department of Statistics Malaysia, 2015). A total of 135 entrepreneurs took part in this study. This number had been determined by taking into account the practices in previous studies, the sample's ability to represent the population and also the rule of thumb for the usage of the data analysis technique, which is a minimum linear regression of about 108 for a medium-sized case at $\alpha=0.01$ with three variables (Cohen, 1988). The sample selection for this study was conducted using cluster sampling followed by simple random sampling.

\section{Study Instruments}

This study is in the form of a survey on the sample using a questionnaire as an instrument for obtaining data. The items used to measure the constructs studied had been adapted and modified from studies by Maizaitulaidawati (2015) and Noor Ashikin (2014). The items for all variables in the study were based on the 7-point Likert scale.

\section{Data Analysis}

The analysis for this study involved two kinds of statistics which are descriptive and inferential. The descriptive statistical analysis involved the analysis of frequency, mean and standard deviation (Othman, 2015; Zikmund \& Babin, 2006) utilising the Statistical Package for Social Sciences (SPSS) software. Specifically, the distribution diagram explains number of frequency, percentage and standard deviation used to summarise the respondents' profiles (Huck, 2012).

Next, the inferential statistical analysis was utilised to analyse data related to the microentrepreneurs' behaviour, with aspects such as attitude, subjective norms and perceived behavioural control influencing the tendency of micro-entrepreneurs to participate in micro-takaful. The analysis was conducted to identify the extent of the micro-entrepreneurs' behaviour, involving attitude, subjective norm and perceived behavioural control, in influencing the tendency of micro-takaful participation among micro-entrepreneurs. Multiple linear regression was employed in this study due to its suitability in testing the relationship between two or more factors which would contribute towards a change in dependent variable (Pallant, 2015).

The position of reliability and validity for each construct in the study is shown in Table 2 . There were four constructs which went through each reliability and validity test: tendency to participate in micro-takaful, attitude, subjective norms and perceived behavioural control. The overall reliability level for each construct was satisfactory with a Cronbach's Alpha exceeding 0.70 (Hair et al., 2010). 
INTERNATIONAL JOURNAL OF ACADEMIC RESEARCH IN BUSINESS AND SOCIAL SCIENCES Vol. 8, No. 11, Nov, 2018, E-ISSN: 2222-6990 @ 2018 HRMARS

Table 2: Reliability Analysis for the Measurement Scale

\begin{tabular}{llcc}
\hline \multicolumn{1}{c}{ Variable } & Cronbach's Alpha Value & Number of Items \\
\hline 1. Tendency of Micro-Takaful Participation & 0.945 & 8 \\
2. Attitude & 0.962 & 4 \\
3. Subjective Norms & 0.941 & 8 \\
4. Perceived Behavioural Control & 0.934 & 6 \\
\hline
\end{tabular}

Table 3 shows the Kaiser-Meyer-Olkin (KMO) value exceeding 0.6 with a significant Bartlett's test value which indicated that the data was sufficient to conduct a factor analysis. (Zuraidah et al., 2014).

Table 3: KMO and Bartlett's Test Results

\begin{tabular}{|c|c|}
\hline \multicolumn{2}{|l|}{ KMO and Bartlett's test } \\
\hline $\begin{array}{l}\text { Kaiser-Meyer-Olkin Measure of Sampling } \\
\text { Adequacy }\end{array}$ & 0.928 \\
\hline Approx. Chi-Square & 4248.216 \\
\hline Bartlett's Test of Sphericity $\quad d f$ & 325 \\
\hline Sig. & 0.000 \\
\hline
\end{tabular}

The EFA results in Table 4 produced 4 factors with a variance value explained at 79.0 percent.

Table 4: The Variance Results Explained

\begin{tabular}{cccc}
\hline & \multicolumn{3}{c}{ Rotation Sums of Squared Loadings } \\
\cline { 2 - 4 } Component & Total & $\begin{array}{c}\text { \% } \\
\text { Variance }\end{array}$ & $\begin{array}{c}\text { Cumulative } \\
\%\end{array}$ \\
\hline 1 & 7.780 & 29.921 & 29.921 \\
2 & 4.844 & 18.630 & 48.551 \\
3 & 4.116 & 15.830 & 64.381 \\
4 & 3.802 & 14.635 & 79.015 \\
\hline
\end{tabular}

\section{Study Findings}

To ensure that the assumptions for the multiple linear regression analysis had been fulfilled, a preliminary test was conducted comprising a test to determine normal distribution of the data, and the presence of outliers and multicollinearity issues. A normal data distribution can be determined from a skewness and kurtosis test. If the values of skewness and kurtosis are in the range of \pm 2 , then the data can be considered as normally distributed (Garson, 2012). Regarding the values of skewness and kurtosis for all items in the study, it was found that the items were in the range of \pm 2 . As such, the normality assumption had been fulfilled.

To assess the existence of extreme values (outliers), two tests were conducted: a standardized $z$-score to identify the univariate outliers and a Mahalanobis $D^{2}$ test to identify the multivariate outliers. Observation on the values of the standardized z-score also found that there were no values exceeding \pm 4 , as such; there were no extreme values in the data (Hair et al., 2010). 
Observation on the values also did not manage to find any Mahalanobis $D^{2}$ value which was significant at the alpha 0.001 (Hair et al., 2010); thus this result revealed no evident multivariate outliers (Table 5). Therefore, this study data was free from univariate as well as multivariate extreme values, and the assumption of the required outliers was also fulfilled.

Table 5: Results of Maximum Mahalanobis $D^{2}$ Value

\begin{tabular}{|c|c|c|c|c|c|}
\hline & Minimum & Maximum & Mean & $\begin{array}{l}\text { Standard } \\
\text { Deviation }\end{array}$ & $\mathrm{N}$ \\
\hline $\begin{array}{c}D^{2}(d f=1, \\
p 1<0.001)\end{array}$ & 0.028 & 13.290 & 2.978 & 2.853 & 135 \\
\hline
\end{tabular}

Additionally, the multicollinearity issue was identified by conducting a test for 2 values, which were tolerance and variance inflation factor (VIF). Based on the rule of thumb, the multicollinearity issue exists if the tolerance value is less than the value suggested at 0.2 (Garson, 2012) and the VIF value exceeds the value suggested, which is 10 (Pallant, 2015). The collinearity statistics results (Table 6) showed that the tolerance value was in the range of 0.996 to 1.000 and the VIF value was in the range of 1.000 to 1.004 . As such, the tolerance value for all the independent variables was bigger than the suggested value, which was 0.2 with a VIF value less than the suggested value of 10 . This result thus showed that there was no multicollinearity issue which could influence the study findings.

Table 6: Collinearity Test

\begin{tabular}{lcc}
\hline \multicolumn{1}{c}{ Independent Variable } & \multicolumn{2}{c}{ Dependent Variable } \\
\hline & \multicolumn{2}{c}{ Tendency of Micro-Takaful Participation } \\
\cline { 2 - 3 } Attitude & Tolerance & VIF \\
\cline { 2 - 3 } Subjective Norms & 0.632 & 1.582 \\
Perceived Behavioural Control & 0.268 & 3.727 \\
\hline
\end{tabular}

As all the assumptions for the linear regression analysis had been fulfilled, it could be summarized that the study data were suitable for further analysis.

\section{The Behavioural Model on the Tendency of Micro-Takaful Participation}

A simple linear regression analysis was conducted to fulfil the study objective which was to analyse the influence of attitude, subjective norms and perceived behavioural control on the tendency of micro-entrepreneurs to participate in micro-takaful scheme.

Based on the multiple linear regression analysis (Table 7), the $R^{2}$ value for the model was 0.719. This indicated that 71.9 percent of the variation in the tendency to participate in micro-takaful (dependent variable) could be explained by the three variables: attitude, subjective norms and perceived behavioural control. The ANOVA table showed the $F$ value $(3,131)=111.802$ with a $p$-value (0.000) less than $\alpha(0.001)$. As such, at least one out of three independent variable tested had a significant linear relationship with the dependent variable. In other words, at least one of the factors 
INTERNATIONAL JOURNAL OF ACADEMIC RESEARCH IN BUSINESS AND SOCIAL SCIENCES

Vol. 8, No. 11, Nov, 2018, E-ISSN: 2222-6990 @ 2018 HRMARS

tested, which could either be attitude, subjective norms or perceived behavioural control, would have a significant relationship with the tendency to participate in micro-takaful.

Table 7: Results of the Multiple Linear Regression Analysis (Summary of Model and Anova)

\begin{tabular}{ccccc}
\hline Model & $\mathrm{R}$ & $\mathrm{R}^{2}$ & Adjusted $\mathrm{R}^{2}$ & Std. Error of the Estimate \\
\hline \multirow{3}{*}{1} & 0.848 & 0.719 & 0.713 & 0.78024 \\
\cline { 2 - 5 } & \multicolumn{3}{c}{$\mathrm{F}$} & $\mathrm{sig}$ \\
\cline { 2 - 4 } & \multicolumn{3}{c}{$111.802^{* * *}$} & 0.000 \\
\hline
\end{tabular}

Note: ${ }^{* * *}$ significant with $\alpha=0.001,{ }^{*}$ significant with $\alpha=0.005,{ }^{*}$ significant with $\alpha=0.05$.

To identify whether there exist a significant relationship between the independent variable and the dependent variable, the $p$-value and standardized beta value were assessed. The findings in Table 8 showed that the three independent variable tested, which were attitude $(p=0.000, p<0.001)$, subjective norms $(p=0.004, p<0.005)$ and perceived behavioural control $(p=0.000, p<0.001)$, had a significant and positive relationship towards the tendency on micro-takaful participation. Apart from that, the standardised beta value showed the factor of perceived behavioural control $(\beta=0.444)$ as a dominant factor in influencing the participation on micro-takaful, followed by the factor of subjective norms $(\beta=0.262)$ and attitude $(\beta=0.240)$. As such, it could be determined that the higher the attitude, subjective norms and perceived behavioural control, the more likely those microentrepreneurs would participate on micro-takaful protection.

Table 8: Results of Multiple Linear Regression Analysis (Coefficient)

\begin{tabular}{ccccc}
\hline \multirow{2}{*}{ Model } & Independent variable & $\begin{array}{c}\text { Standardised Beta } \\
\text { coefficient }\end{array}$ & $t$ & Significant \\
\hline \multirow{2}{*}{1} & Attitude *** & 0.240 & 4.113 & 0.000 \\
& Subjective Norms** & 0.262 & 2.926 & 0.004 \\
& Perceived Behavioural Control*** & 0.444 & 4.808 & 0.000 \\
\hline
\end{tabular}

Note:

Dependent variable: Tendency to participate in micro-takaful

$* * *$ significant with $\alpha=0.001,{ }^{*}$ significant with $\alpha=0.005,{ }^{*}$ significant with $\alpha=0.05$.

The summary for the results of the test can be seen in Table 9.

Table 9: Summary of the Hypothesis Testing Result

\begin{tabular}{lll}
\hline & \multicolumn{1}{c}{ Hypothesis } & Result \\
\hline$H_{1}:$ & $\begin{array}{l}\text { Attitude has a significant influence on the tendency of micro- } \\
\text { takaful participation. }\end{array}$ & Supported \\
$H_{2}:$ & $\begin{array}{l}\text { Subjective norm has a significant influence on the tendency } \\
\text { of micro-takaful participation. }\end{array}$ & Supported \\
$H_{3}:$ & $\begin{array}{l}\text { Perceived behavioural control has a significant influence on } \\
\text { the tendency of micro-takaful participation. }\end{array}$ & Supported \\
\hline
\end{tabular}




\section{Discussion}

This study aims to analysis the tendency of micro-entrepreneurs to participate in micro-takaful schemes. The data collected among the micro-entrepreneurs in Perak showed that the suggested model was effective in predicting the tendency of the entrepreneurs in micro-takaful participation.

The findings revealed that the TPB model could explain the 79.0 percent variance of the tendency to participate in micro-takaful schemes. The data showed that attitude, subjective norms and perceived behavioural control were important factors in determining the willingness of the micro-entrepreneurs to participate in the micro-takaful schemes.

The findings showed in detail that perceived behavioural control was the main factor in influencing the tendency to take part in micro-takaful schemes. This proved that microentrepreneurs with positive perceptions such as those who had access to resources and facilities would be likely and willing to participate in these micro-takaful schemes. Such a significant influence is parallel with the findings from Ajzen (1985), Alam et al. (2012), Alam and Sayuti (2011) and Nik Safiah and Norazlina (2015). Additionally, the subjective norm factor also had a significant influence with the tendency to join the micro-takaful schemes. These findings indicated that the greater the influence from others, the more likely that micro-entrepreneurs would participate in the schemes mentioned. These findings are parallel with the findings from Abdullah et al. (2014), Mohd Azizi et al. (2017) and Hanudin (2012). Similarly, the attitude factor had a direct and significant influence on the tendency on micro-takaful participation. This clearly shows that micro-entrepreneurs with a highly motivation would be attracted to join these schemes. As such, this indicates that the study findings are in line with previous studies by Ajzen and Fishbein (1980), Maizaitulaidawati and Asmak (2016), Mohd. Azizi et al. (2017) and Mohamad Rohieszan et al. (2018).

\section{Implications and Conclusion}

The study findings contribute towards theoretical and practical implications. Based on the theoretical perspective, this study provides additional empirical evidence to the existing literature related to the need for a micro-takaful scheme as an initiative to minimise the loss caused by the microentrepreneurs' involvement in the risk of uncertainty.

From the practical aspect, this study is in line with the government's policy to increase financial inclusion among the Bottom 40\% (B40) and Middle 40\% (M40) segments. This study aims to provide a new dimension not just for the academicians, but also for the micro-takaful entrepreneurs. To increase the micro-takaful participation, micro-takaful providers and policy makers should build a positive entrepreneurial attitude by creating awareness in the society about the role of micro-takaful in financial inclusion which aims to eradicate poverty and improve society's wellbeing. Therefore, policy makers such as the Ministry of Entrepreneur Development of Malaysia should promote the micro-takaful product to all segments of the societies so that the public can understand the benefits of the scheme. From the aspect of perceived behavioural control, micro-takaful providers should take into account the ability of micro-takaful entrepreneurs to participate in the schemes in terms of contributing (low) premiums, easy policy documentation and faster and easier claims procedure. It is imperative that the policy makers and takaful institutions to be more proactive and improve the micro-takaful system as well as upgrade the product's accessibility by expanding the service to post office, markets, zakat centres, wakaf institutions and cooperatives. Additionally, information should 
INTERNATIONAL JOURNAL OF ACADEMIC RESEARCH IN BUSINESS AND SOCIAL SCIENCES

Vol. 8, No. 11, Nov, 2018, E-ISSN: 2222-6990 @ 2018 HRMARS

be disseminated about the importance of micro-takaful schemes to guarantee protection, safety and the rights of micro-entrepreneurs in Perak as well as the whole of Malaysia.

\section{Acknowledgement}

This research is funded by Universiti Pendidikan Sultan Idris Research Grant (2017-0165-106-01).

\section{Corresponding Author}

Azila Abdul Razak

Department of Economics, Faculty of Management and Economics, Universiti Pendidikan Sultan Idris, Malaysia

Email: azila@fpe.upsi.edu.my

\section{References}

Abdullah, A. S., Sheikh Mohammed Rafiul, H., Muhammad Haroon, H., \& Mohd Noor, M. S. (2014). The role of subjective norms in theory of planned behaviour in the context of organic food consumption. British Food Journal, 116(10), 1561-1580. https://doi.org/10.1108/BFJ-05-2013-0105.

Ahmed, M. H. (2016). Micro-takaful insurance as a tool to guaranteeing financing and protecting micro enterprises. Journal of Business \& Financial Affairs, 5(4), 1-11. doi: 10.4172/2167-

0234.1000228

Ajzen, I. (1991). The theory of planned behaviour. Organizational Behaviour and Human Decision Processes, 50(2), 179-211. https://doi.org/10.1016/0749-5978(91)90020-T.

Ajzen, I., \& Fishbein, M. (1980). Understanding Attitudes and Predicting Social Behaviour. Englewood Cliffs, NJ: Prentice-Hall.

Billah, M. M. (2003). Islamic and Modern Insurance (Principles and Practices). Kuala Lumpur: Ilmiah Publishers.

Cohen, J. (1988). Statistical Power Analysis for the Behavioural Sciences. (2nd Ed.). Hillsdale, NJ: Lawrence Erlbaum Associates, Publishers.

Department of Statistics Malaysia. (2015). Economic Census 2016: Profile of SMEs.

Doane, A. N., Kelley, M. L., \& Pearson, M. R. (2016). Reducing cyberbullying: a theory of reasoned action-based video prevention program for college students. Aggressive Behaviour, 42(2), 136-146. doi: 10.1002/ab.21610. Epub 2015 Sep 9.

Fatin Nabilah, A. W. (2015). Kajian Pelaksanaan Skim Takaful Mikro di Malaysia, Master Thesis, University of Malaya (unpublished).

Fatin Nabilah, A. W. \& Kamaruzaman, N. (2014). Skim takaful sumbangan rendah serta prospek perlaksanaan takaful mikro di Malaysia. International Conference on Postgraduate Research (ICPR2014).

Fishbein, M., \& Ajzen, I. (1975). Belief, Attitude, Intention, and Behaviour. Reading, MA: AddisonWesley.

Hair, Joseph F., William C. Black, Barry J. Babin, Rolph E. Anderson, \& Tatham, R. L. (2010). Multivariate Data Analysis: A Global Perspective. (7th Ed.). New York Person Education Inc. 
Hanudin, A. (2012). An analysis on Islamic insurance participation. Jurnal Pengurusan, 34, 11- 20. Kwon, W. J. (2010). An analysis of organisational, market and socio-cultural factors affecting the supply of insurance and other financial services by microfinance institutions in developing economies. Geneva Papers on Risk and Insurance - Issues and Practice, 35(1), 130-160.

Kwon, W. J. (2008). Islamic principle and takaful insurance: re-evaluation. Journal of Insurance Regulation, 26(1), 53-81.

Maizaitulaidawati, M. H. (2015). Muslim Intention to Particpate into Family Takaful Scheme: A Study Using Decomposed Theory of Planned Behaviour in Klang Valley, Malaysia, Ph.D Thesis, University of Malaya (unpublished).

Maizaitulaidawati, M. H. \& Asmak, A. R. (2016). Predicting intention to participate in family takaful scheme using decomposed theory of planned behaviour. International Journal of Social Economics, 43(12), 1351-1366. https://doi.org/10.1108/IJSE-03-2015-0074.

Marhanum, C. M. S. \& Fatimah Zaharah, P. (2018). The prevalence of micro-takaful products in the eyes of Malaysian SMEs. International Academic Institute for Science and Technology, 5(3), 49-65.

Mohamed Sherif \& Nor Azlina, S. (2013). Determinants of demand on family takaful in Malaysia.

Journal of Islamic Accounting and Business Research, 4(1), 26-50. https://doi.org/10.1108/17590811311314276.

Mohd Azizi, I., Wan Nazjmi M. F., \& Yusuf H. O. (2017). Customer intention on Islamic home financing products: an application of theory of planned behaviour (TPB). Mediterranean

Journal of Social Sciences, 8(2), 77-86. DOI: 10.5901/mjss.2017.v8n2p77.

Nik Safiah, N. A. \& Norazlina, A. W. (2015). Investigating factors affecting the intention to use Islamic personal financing. International Journal of Management Studies, 22, 47-60.

Norashikin, I., Akmal Aini, O., Nur Liyana, M. Y., Syaidatul Zarina, M. D., Norsaliza, A. B., Mohd Khairul Ariff, N. dan Roslina, M. S. (2013). A study of the awareness level of takaful products among micro enterprises in Malaysia. Journal of Modern Accounting and Auditing, 9(11), 1535-1542.

Noor Ashikin, M. R. (2014). The Development of a Microtakaful Model to Serve the Underprivileged: Low Income and the Poor in Selected States in Malaysia, Ph.D Thesis, Universiti Teknologi MARA (unpublished).

Nurul Aien, A. A., Zuriah, A. R., \& Yon Bahiah, W. A. (2014). Factors contributing to paddy farmers' intention to participate in agriculture takaful. Proceedings of the 1st AAGBS International Conference on Business Management 2014 (AiCoBM 2014).

Pallant, J. (2015). SPSS Survival Manual: A Step Guide to Data Analysis Using SPSS. (6th Ed.). Australia: Publish Allen \& Unwin.

Sheila, N. N. H., Nur Shazwani, S., \& Hanudin, A. (2015). An analysis of the viability of micro health takaful in Malaysia. Qualitative Research in Financial Markets, 7(1), 37-71. https://doi.org/10.1108/QRFM-09-2013-0030.

Syed Shah Alam, Hawati, J., Zanariah, Che Aniza, C. W., \& Mst. Nilufar, A. (2012). Is religiosity an important factor in influencing the intention to undertake Islamic home financing in Klang Valley? World Applied Sciences Journal, 19(7), 1030-1041. DOI: 10.5829/idosi.wasj.2012.19.07.392. 
Alam, S. S. \& Nazura, M. S. (2011). Applying the theory of planned behaviour (TPB) in halal food purchasing. International Journal of Commerce and Management, 21(1), 8-20. https://doi.org/10.1108/10569211111111676.

Untaru, E.-N., Ispas, A., Candrea, A. N., Luca, M., \& Epuran, G. (2016). Predictors of individuals' intention to conserve water in a lodging context: the application of an extended theory of reasoned action. International Journal of Hospitality Management, $\quad$ 50-59. https://doi.org/10.1016/j.ijhm.2016.09.001.

Zuraidah, Z., Norjaya, M. Y., Nor Asiah, O., \& Nik M. Hazrul, N. H. (2014). Determining the key factors of customer-brand relationship investments' dimensions: insights from Malaysian mobile phone user. Journal of Relationship Marketing, 13(4), 1-25. https://doi.org/10.1080/15332667.2014.965649.

Zuriah, A. R., Rosylin, M. Y., \& Faizah, A. B. (2008). Family takaful: it's role in social economic development and as a savings and investment instrument in Malaysia - an extension. Jurnal Syariah, 16(1), 89-105. 